\title{
Antioxidant activity of collagen hydrolysate obtained from tilapia scales in vitro and in vivo assays
}

\author{
ShaoKui ZENG ${ }^{a}$, Wenlong WU, ChaoHua ZHANG ${ }^{*}$, JuanJuan YIN, ZhenLin LI
}

College of Food Science and Technology, Guangdong Ocean University, Guangdong Provincial

Key Laboratory of Aquatic Product Processing and Safety, Key Laboratory of Advanced Processing of Aquatic Products of Guangdong Higher Education Institution, Zhanjiang 524088, China

azsk1105@126.com, ”chz2382@126.com

Keywords: Tilapia scale; collagen hydrolysate; antioxidant

Abstract. Collagen hydrolysate of S and $\mathrm{C}$ were prepared by enzymatic hydrolysis decalcified tilapia scale and pepsin-solubilised collagen extracted from decalcified tilapia scale. The antioxidative activity of $\mathrm{C}$ and $\mathrm{S}$ were evaluated by their effects on scavenging ability of superoxide anion $\mathrm{O}^{2-}$ radicals, 1,1-diphenyl-2-picrylhydrazyl (DPPH) radicals and reductive ability in vivo. Besides, the activity of glutathione peroxidase (GSH-Px), total antioxidant capacity (T-AOC) and content of malondialdehyde (MDA) in vitro of the laboratory mouse were detected. The results indicated that collagen hydrolysate of $\mathrm{C}$ and $\mathrm{S}$ show prominent inhibitory effect on scavenging $\mathrm{O}^{2-}$ with the fifty-percent inhibitory concentration $\left(\mathrm{IC}_{50}\right)$ of 3.7 and $6.5 \mathrm{mg} / \mathrm{mL}$, respectively. The $\mathrm{IC}_{50}$ of collagen hydrolysate of $\mathrm{C}$ and $\mathrm{S}$ inhibit the DPPH were 8.4 and $7.2 \mathrm{mg} / \mathrm{mL}$, respectively. Two collagen hydrolysates demonstrated highly reducing activity. In vivo experimentation suggested that $\mathrm{C}$ and $\mathrm{S}$ can significantly improve the GSH-Px activity, T-AOC and reduce the contents of MDA. As a consequence of results, collagen hydrolysates of $\mathrm{C}$ and $\mathrm{S}$ extracted from decalcified tilapia scale have a good antioxidation.

\section{Introduction}

Tilapia is economically important freshwater fishes widely cultured in the world and China's annual output in 2013 is about 1.66 million ton. During tilapia fillet processing, large quantities of by-products such as skin and scale are produced. Collagen content is very rich in tilapia scale [1]. So far, a number of studies have reported antioxidant activity of protein hydrolysates derived from fish processing by-product wastes, such as tuna backbones, Sardinella aurita heads and viscera and Mediterranean fish discarded, Sphyrna lewini, Dasyatis akjei and Raja porosa cartilage [2,3,4]. Therefore, the aims of this work were to investigate antioxidant activity of collagen hydrolysate obtained from tilapia scales in vitro and in vivio assays.

\section{Materials and methods}

\section{Materials}

Decalcified tilapia scales were provided by Leizhou Northbay Aquatic Product Co., Ltd. The contents of crude protein, collagen and carbohydrate of the scale were $76.9,61.0$ and $0.2 \%(\mathrm{w} / \mathrm{w})$, respectively. Food-grade neutral protease from Bacillus subtilis 1398 and papain from papaya latex were purchased from Pangbo Biological Engineering Co. Vitamin C $\left(\mathrm{V}_{\mathrm{C}}\right)$ was purchased from Sangon Biological Engineering Technology \& Services Co. 1,1-diphenyl-2-picrylhydrazyl (DPPH) and hydroxyproline were purchase from Sigma Chemical Co. Male Kunming mice (20 $\pm 2 \mathrm{~g})$ were purchased from the Experimental Animal Center of Guangdong Medical College.

\section{Methods}

Extraction of pepsin-solubilised collagen. Pepsin-solubilised collagen (PSC) was extracted from the decalcified tilapia scales according to the method of Zeng [1].

Collagen hydrolysate preparation. The decalcified scales and PSC were digested with neutral protease and papain $(1: 1)$ at temperature of $65^{\circ} \mathrm{C}, \mathrm{pH}$ of 6.0 , enzyme (U)-to-substrate $(\mathrm{g})$ ratio of 1000:1 and liquid-solid ratio 1:5 for $3 \mathrm{~h}$, respectively. After hydrolysis, the liquids were heated in a 
boiling water bath $\left(100{ }^{\circ} \mathrm{C}\right)$ for $10 \mathrm{~min}$ to inactivate the protease, and centrifuged at $4000 \mathrm{~g}$ for $10 \mathrm{~min}$. The supernatants were spray-dried and referred to as collagen hydrolysate of S and C, respectively.

Determination of proximate components. The proximate composition was determined according to AOAC official methods [5]. Total carbohydrate content of samples was determined by the phenol-sulfuric acid method [6].

Amino acid analysis. Collagen hydrolysates were dissolved in $2 \mathrm{~mL}$ of $6 \mathrm{M} \mathrm{HCl}$, respectively. The mixture was evacuated, vacuum-sealed and hydrolyzed at $110{ }^{\circ} \mathrm{C}$ for $24 \mathrm{~h}$. Then the hydrolysate was vaporised and the residue was dissolved in $25 \mathrm{~mL} 0.1 \mathrm{M} \mathrm{HCl}$. An aliquot of $0.05 \mathrm{~mL}$ was applied to an amino acid analyzer (HITACHI 835-50 Amino Acid Analyzer, Tokyo, Japan). Hydroxyproline was added into the amino acid mixture standard and then the standard includes 17 kinds of amino acids.

Superoxide anion $\mathrm{O}^{2-}$ radicals scavenging assay. Scavenging ability of superoxide anion $\mathrm{O}^{2-}$ radicals of collagen hydrolysate was determined according to the method of Guo [7]. The scavenging rate for superoxide anion $\mathrm{O}^{2-}$ was calculated as:

$$
\mathrm{O}^{2-} \text { radical scavenging rate }(\%)=\left(1-\mathrm{V}_{\mathrm{t}} / \mathrm{V}_{0}\right) \times 100
$$

The EC50 value was defined as the concentration of sample $\left(\mathrm{mg} \cdot \mathrm{mL}^{-1}\right)$ required to scavenge $50 \%$ of superoxide anion $\mathrm{O}^{2-}$ radicals.

DPPH radical scavenging assay. The DPPH-radical scavenging activity was measured according to the method described by Bortolomeazzi [8]. The antioxidant activity of the sample was evaluated by the inhibition percentage of DPPH with the following equation:

DPPH-radical Scavenging rate $(\%)=\left(1+\left(A_{b}-A_{s}\right) / A_{o}\right) \times 100$

Where, $A_{s}, A_{0}$ and $A_{b}$ were the absorbance of the reaction solution with sample, control group and blank, respectively. Ascorbic acid $\left(\mathrm{V}_{\mathrm{C}}\right)$ was used as a positive control. The $\mathrm{EC}_{50}$ value was defined as the concentration of sample $\left(\mathrm{mg} \cdot \mathrm{mL}^{-1}\right)$ required to scavenge $50 \%$ of DPPH-radical.

Reducing power assay. The reducing power was measured according to the procedure described by Zhu [9].

Measurement of malondialdehyde (MDA) level, activity of GSH-px and total antioxidant capacity in mouse liver. Male Kunming mice were group-housed (10 mice per cage) with free access to food and water, and kept in a regulated environment at $25 \pm 1^{\circ} \mathrm{Cunder} 12 \mathrm{~h} \mathrm{light} / 12 \mathrm{~h}$ dark conditions. After 1 week of acclimatization to the home cage, the mice were randomly divided into four groups. In the experimental session, the normal control group (NG) mice were i.p. injected with $0.3 \mathrm{ml}$ of saline and the positive control group (group PC) mice, collagen hydrolysate treatment group (group CA and $\mathrm{CB})$ mice were intragastric administration with ginseng royal jelly, hydrolysate $\mathrm{S}$ and $\mathrm{C}\left(50 \mathrm{mg} \cdot \mathrm{kg}^{-1}\right)$ once daily for 30 days, respectively. After the final intragastric administration for $30 \mathrm{~min}$, mice were put in swimming box to swim for $90 \mathrm{~min}$ and then decapitated. Their livers were removed rapidly and homogenized in cold saline. The homogenate $(10 \%)$ was centrifuged at $3000 \mathrm{~g}$ at $4{ }^{\circ} \mathrm{C}$ for $20 \mathrm{~min}$, and the supernatant was used for an assay. The thiobarbituric acid reaction (TBAR) method was used to determine the MDA (detected at $532 \mathrm{~nm}$ ) [10]. MDA content was expressed as nanomoles per milligram of liver. The activity of GSH-px was determined by quantifying the catalyzed reaction rate of $\mathrm{H}_{2} \mathrm{O}_{2}$ and GSH. One unit (U) of GSH-px was defined as the amount that reduced the level of GSH by $1 \mu$ mol. Total antioxidant capacity was determined used assay kit with 2,2-azinobis-3-ethylbenzothiazoline-6-sulfonic acid (ABTS) method.

Statistical analysis. The experimental results were performed in triplicate. The data were recorded as mean \pm standard deviation and analysed by SPSS (version 11.5 for Windows 2000, SPSS Inc.).

\section{Results and discussion}

Proximate components. The proximate components of collagen hydrolysate S and $\mathrm{C}$ were shown in Table 1. 
Table 1 The proximate components of collagen hydrolysate (\%)

\begin{tabular}{ccccc}
\hline Samples & Moisture & Crude protein & Carbohydrate & Ash \\
\hline S & $6.59 \pm 0.12^{\mathrm{a}}$ & $86.25 \pm 0.37^{\mathrm{b}}$ & $3.58 \pm 0.21^{\mathrm{a}}$ & $0.67 \pm 0.03^{\mathrm{c}}$ \\
$\mathrm{C}$ & $8.03 \pm 0.17^{\mathrm{a}}$ & $85.09 \pm 0.54^{\mathrm{b}}$ & $3.86 \pm 0.30^{\mathrm{a}}$ & $0.64 \pm 0.07^{\mathrm{c}}$ \\
\hline
\end{tabular}

Note: Values for a particular column followed by different letters differ significantly.

The contents of proximate components of collagen hydrolysate $\mathrm{S}$ and $\mathrm{C}$ were similar $(P>0.05)$. They are rich in protein.

Amino acid composition. The amino acid composition of hydrolysate $\mathrm{S}$ and $\mathrm{C}$ is shown in Table 2.

Table 2 Amino acid composition of hydrolysate S and C (g/100g)

\begin{tabular}{lll}
\hline Amino acids & $\mathrm{S}$ & $\mathrm{C}$ \\
\hline Asparagine & 4.88 & 5.05 \\
Threonine & 2.63 & 2.50 \\
Serine & 3.03 & 3.01 \\
Glutamine & 8.10 & 8.01 \\
Glycine & 19.92 & 20.34 \\
Alanine & 11.02 & 11.72 \\
Valine & 2.20 & 1.92 \\
Methionine & 1.18 & 1.01 \\
Isoleucine & 1.19 & 0.93 \\
Leucine & 2.27 & 2.36 \\
Tyrosine & 0.81 & 0.53 \\
Phenylalanine & 1.83 & 1.91 \\
Lysine & 1.18 & 0.84 \\
Histidine & 2.67 & 2.94 \\
Arginine & 6.83 & 7.33 \\
Proline & 10.49 & 11.12 \\
Hydroxyproline & 8.92 & 8.06 \\
Total & 89.1 & 89.60 \\
\hline
\end{tabular}

Table 2 suggested that collagen hydrolysate $\mathrm{S}$ and $\mathrm{C}$ mainly contained glycine, alanine, proline, hydroxyproline and glutamine, in which glycine was the most abundant with the amount of $22 \%$ of the total amino acid. It is widely accepted that peptides with high contents of histidine, proline, alanine, valine, methionine, and hydroxyproline possess a strong antioxidant capacity [11].

DPPH radical scavenging activity. DPPH radical scavenging activities of hydrolysate $\mathrm{S}$ and $\mathrm{C}$ are depicted in Fig.1.

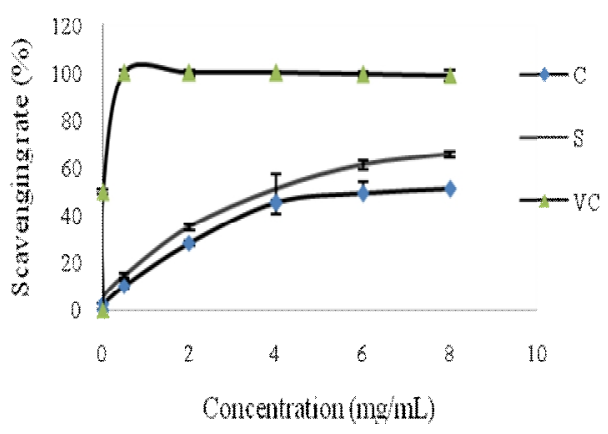

Fig.1 The effect of hydrolysates on scavenging DPPH

Fig. 1 shows the DPPH radical scavenging activity of collagen hydrolysate $\mathrm{S}$ and $\mathrm{C}$ at the highest concentration, were 58.64 and $52.31(\mathrm{mg} / \mathrm{mL})$, respectively. No significant $(P>0.05)$ difference in radical scavenging activity was observed between the two collagen hydrolysates.

Superoxide anion scavenging activity. Fig.2 showed the superoxide anion scavenging activity of hydrolysate $\mathrm{S}$ and $\mathrm{C}$. 


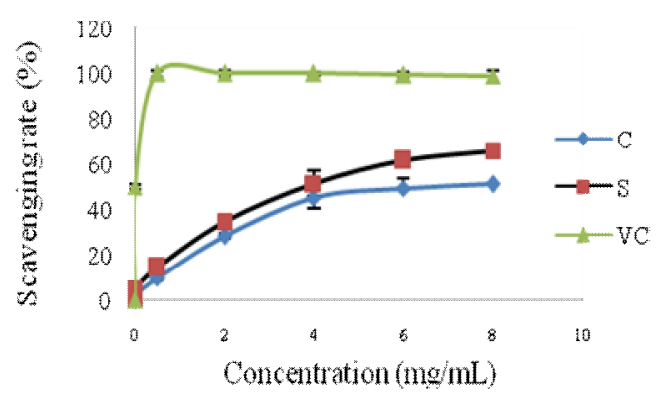

Fig.2 The effect of hydrolysates on scavenging $\mathrm{O}^{2-}$

They have obvious scavenging ability against superoxide anion. The antioxidant activities increased gradually with increasing of the concentration of hydrolysates.

Reducing power. The reducing power of collagen hydrolysates $\mathrm{S}$ and $\mathrm{C}$ is shown in Fig. 3.

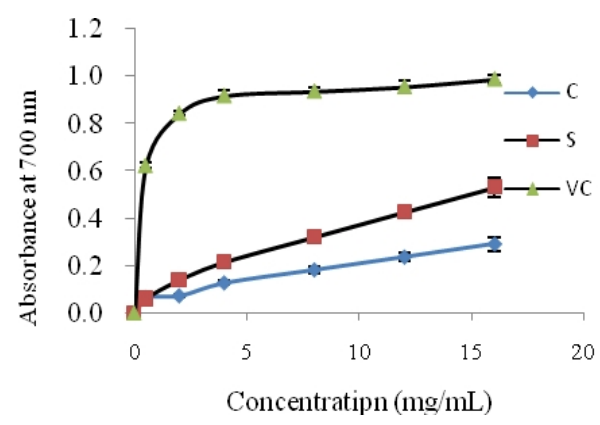

Fig.3 Reducing capacity of collagen hydrolysate

Fig. 3 suggests that collagen hydrolysate exhibited dose-dependent reducing power, showing the ability to reduce ferric ions to ferrous ions.

In vivio antioxidant activity. Antioxidant effects of in mice were showed in Table 3.

Table 3 Effects of hydrolysates on GSH-PX, MDA, T-AOC in liver of mice $(\mathrm{n}=10, \bar{x} \pm s)$

\begin{tabular}{lccc}
\hline Group name & $\begin{array}{c}\text { GSH-Px activity/ } \\
(\mathrm{U} / \mathrm{mg})\end{array}$ & $\begin{array}{c}\text { MDA content/ } \\
(\mathrm{nmol} / \mathrm{mg})\end{array}$ & T-AOC ability \\
\hline Normal control group (NG) & $24.451 \pm 1.826^{\mathrm{d}}$ & $0.798 \pm 0.031^{\mathrm{a}}$ & $0.822 \pm 0.049^{\mathrm{b}}$ \\
Positive control group (PC) & $31.666 \pm 1.032^{\mathrm{a}}$ & $0.537 \pm 0.053^{\mathrm{c}}$ & $1.343 \pm 0.147^{\mathrm{a}}$ \\
S treatment group (A) & $25.407 \pm 1.967^{\mathrm{c}}$ & $0.719 \pm 0.062^{\mathrm{b}}$ & $1.274 \pm 0.244^{\mathrm{a}}$ \\
C treatment group (B) & $25.421 \pm 1.007^{\mathrm{bc}}$ & $0.732 \pm 0.042^{\mathrm{b}}$ & $1.300 \pm 0.244^{\mathrm{b}}$ \\
\hline
\end{tabular}

Note: There were no significantly different between the groups if they were not connected with the same letter.

The results suggested that the $\mathrm{S}$ and $\mathrm{C}$ can improve the total antioxidant capacity significantly. In comparison to NC group mice, collagen hydrolysate $\mathrm{S}$ and $\mathrm{C}$ can decrease the level of MDA and the activity of GSH-px.

\section{Conclusions}

Collagen hydrolysate prepared by hydrolysate decalcified tilapia scale and its pepsin-solubilised collagen (PSC) with pepsin was found to possess the antioxidant activity in vivo and in vitro assays. Therefore, they may serve as a good source of desirable antioxidant peptides for nutraceutical and pharmaceutical ingredients.

\section{Acknowledgements}

This work was supported by the Foundation for Agriculture Science and Technology Research Team of Guangdong (Grant No. 2011A020102005). 


\section{References}

[1] Zeng, S. K., Lan H. M., Zhang, C. H., Hong, P. Z., Study on the extraction of collagen from scale of tilapia and antioxidant activity of its hydrolysate. Shanghai Ocean Univ. 18 (2009) 599-603.

[2] Je JY, Qian Z, Byun H, Kim S., Purification and characterization of an antioxidant peptide obtained from tuna backbone protein by enzymatic hydrolysis. Process Biochem. 42 (2007) 840-846.

[3] Souissi N, Bougatef A, Triki-Ellouz Y, Nasri M., Biochemical and functional properties of Sardinelle (Sardinella aurita) by-product hydrolysates. Food Technol Biotech. 45 (2007) 187-194.

[4] García-Moreno PJ, Batista I, Pires C, et al. Antioxidant activity of protein hydrolysates obtained from discarded Mediterranean fish species. Food Res Int 65 (2014) 469-476.

[5] Horwitz, W. Official Methods of Analysis of the Association of Official Analytical Chemists, 17th edn. Washington DC, USA: AOAC International, 2000.

[6] DuBois M, Gilles KA, Hamilton JK, Rebers PA, Smith F., Colorimetric method for determination of sugars and related substances. Anal Chem. 28 (1956) 350-356.

[7] GUO XF, YUE YD, TANG F, WANG J, \& YAO X. Detection of antioxidative capacity of bamboo leaf extract by scavenging superoxide anion free radical. Spectroscopy Spectral Anal. 28 (2008)1823-1826.

[8] Bortolomeazzi R, Sebastianutto N, Toniolo R, Pizzariello A., Comparative evaluation of the antioxidant capacity of smoke flavouring phenols by crocin bleaching inhibition, DPPH radical scavenging and oxidation potential. Food Chem. 100 (2007) 1481-1489.

[9] Zhu L J, Chen J, Tang XY, Xiong Y L., Reducing, radical scavenging, and chelation properties of in vitro digests of alcalase-treated zein hydrolysate. J Agr Food Chem. 56 (2008) 2714-2721.

[10] Ohkawa H, Ohishi N, Yagi K., Assay for lipid peroxides in animal tissues by thiobarbituric acid reaction. Anal Biochem. 95 (1979) 351-358.

[11] Guo H, Kouzuma Y, Yonekura M. Structures and properties of antioxidative peptides derived from royal jelly protein. Food Chem. 113 (2009) 238-245. 